\title{
EVOLUTIONAL CHANGES IN MODERN THINKING IN MEDICAL STUDENTS AND THEIR INTEGRATION IN HIGHER MEDICAL EDUCATION
}

\section{Barannik K. S.}

\section{INTRODUCTION}

It is known that the increasing role of information, information technology has led to the fact that modern society exists at a new stage of development - information. There is a fundamentally new way of communicating and broadcasting information, dubbed «screen culture.» In fact, a new habitat for human beings is being formed - an information society, the specificity of which is the transmission of information by means of a moving image supplemented by sounds. The impact of the information society touches upon the spheres of people's society, their learning and governance processes. Under his influence there is a change of thinking, in connection with which more and more often in the scientific literature such concepts as «man-screen», «clip-thinking», «clip-consciousness» appear ${ }^{1}$. Due to the informatization of education, which is now considered almost a panacea, there are risks of the loss of the creative cultural and generational capacity of whole generations. If the older generation still retains other forms of perception of the information provided (comprehension, comparison, analysis, criticism, etc.), then the younger generation, and students in the first place, is increasingly dynamic, mosaic, «clip» receiving, processing and imaging information, first of all - educational. Clip thinking «as a phenomenon is a response to the growing amount of information. The media have developed a universal format for submitting information, the essence of which is to submit a set of abstracts or clips without defining context, because because of its relevance, the context for the thesis is objective reality. In other words, the universal media format forces events to be related if they have a temporary affinity rather than a factual one. The society, being at the present stage of development, is transformed into an «electronic society» or «global village» «And defines, through electronic

\footnotetext{
${ }^{1}$ Barannyk S.I., Yekhalov V.V., Romanyuta I.A., Lyashchenko P.V. (2018). Intehratsiya «klipovoho myslennya» v suchasnu vyshchu medychnu osvitu. Pivdennoukrayins'kyy medychnyy naukovy zhurnal. № 19(19) february. pp. 8-12.
} 
means of communication, a multidimensional perception of the world. The development of electronic means of communication returns human thinking to the pre-textual age, and the linear sequence of signs ceases to be the basis of culture. mainly visual and associative, archaic and devoid of temporal and spatial categories, and the individual has no need to remember information, summarize it, and make sense of it. He ceases to acquire objects of knowledge because they are illusory. This specificity of remembering the «electronic personality» entails a corresponding change in thinking reducing the number of desired, sought, meaningful, unknown objects. And the thought, which has lost its problematic components, ceases to generate thoughts, images, symbols, ideas ${ }^{2}$. Clip culture creates unique forms of perception, such as «zapping», «channel zapping», when switching channels of television continuously creates a new image consisting of fragments of information and excerpts. This image does not require connection of imagination, reflection, comprehension. All the time there is a «reboot», «updating» of information, when everything initially seen without a temporary break loses its meaning, that is, becomes obsolete. Modern people, accelerating the pace of change, forever broke with the past. The abandonment of the previous way of thinking, of the previous feelings, of the previously established methods of adaptation to those conditions of life that are constantly changing, contributes to the constant search for one's identity. The acceleration of the pace of life is no longer within the scope of normal human existence, under its pressure all social institutions of society are changing. It was under this continuous informational bombardment of human consciousness that the «clip thinking» was formed. Humanity captures such a psychological previously unknown condition, which in its impact can be equated with illness. This disease also has the name «futuroshok» - «shock of the future.»

Factors that influenced the formation of a new, diffused, defragmented type of thinking:

1. Acceleration of the pace of life and constant increase of information flow.

2. Increasing requirements for the speed of receipt of information and its relevance.

3. Increasing the diversity of incoming information.

4. Increase in the number of cases that a person deals with simultaneously.

${ }^{2}$ Hych H. M. (2016). «Klipove» myslennya molodi: druh chy voroh navchannya? Naukovi pratsi. Pedahohika, vipusk. 257. T. 269. p. 38-42. 
5. The growth of democracy at different levels of the social system: preaching becomes a debate, rhetoric - a dialectic ${ }^{3}$.

6 . The language of images and gestures is much older than the language of symbols, so it is easier for a person to perceive information in the form of images than in a linear form (letters, numbers, formulas, etc.).

In today's society, there has been a steady tendency to form fragmentary provision and to obtain information with a dominance of quantity rather than quality. In psychology, pedagogy and journalism, such thinking is characterized as a clip - fragmentary and illogical ${ }^{4}$. Today, we have to talk about the peculiarities and consequences of such thinking, including:

- inability to handle large amounts of data;

- simplifying information;

- large but haphazard awareness of any issues;

- «clip» is increasingly replacing the meaning of the story structure of the text (context);

- pursuit of external signs and change of impressions, the advantage is given to virtual reality: objective reality also becomes simulative;

- inhibition of the ability to concentrate on one thing for a long time;

- the possibility of being exposed to external influence and manipulation;

- limiting the ability to analyze and build long logical circuits;

- weakening of empathy (compassion), guilt and responsibility;

- permanent over-excitement, rapid fatigue, procrastination (constant postponement of difficult cases «for later»), mental lability.

Often, the complaints that young people read poorly and poorly understand the content of the reading can be heard from the mouth of teachers of different disciplines, the study of which is related to the processing of a large number of primary sources in the form of verbal texts. The same applies to traditional lectures, which suggest that the focus of the listeners over time is focused on one subject. Obviously, traditional teaching methods present serious difficulties for learners with a non-textual type of perception, the number of which is increasing rapidly every year. Experts from different industries who are paying attention to this problem are divided into two camps, which can be conditionally defined as

${ }^{3}$ Yekhalov V.V., Samoylenko A.V., Romanyuta I.A., Barannyk S.I. (2018). Klinichne ta «klipove» myslennya u likariv-interniv. Ukrayins'kyy zhurnal medytsyny, biolohiyi ta sportu. Tom 3, №1(10). pp. 241-244.

${ }^{4}$ Barannyk S.I., Yekhalov V.V., Mizyakina K.V., Barannik K.S. (2019). Evolyutsiyni aspekty «Klipovoho myslennya» u studentiv-medykiv ta yikh intehratsiya u vyshchu medychnu osvitu. «Sotsial'no-humanitarni doslidzhennya ta innovatsiyna osvitnya diyal'nist'» Materialy Mizhnarodnoyi naukovoyi konferentsiyi. 24-25 travnya 2019 r., m. Dnipro / Nauk. red. O.Yu. Vysots'kyy. Dnipro: SPD «Okhotnik». 528 P. pp 435-438. 
«conservative» and «progressive». Conservatives want to keep the perception and consciousness of people within anything within the cognitive style that seems to them to be more sophisticated. In order to prevent the emergence / progression of clip-on thinking, special trainings are offered to help focus more attention, and we recommend reading more classic texts.

Due to the informatization of education, which is now considered almost a panacea, there are risks of the loss of the creative cultural and generational capacity of whole generations. If the older generation still retains other forms of perception of the information provided (comprehension, comparison, analysis, criticism, etc.), then the younger generation, and students in the first place, are increasingly dynamic, mosaic, «clip» receiving, processing and imaging information, first of all - educational. A person cannot concentrate on information for a long time, and his / her ability to analyze is significantly reduced. It is difficult for the owner of the clip thinking to analyze the situation, since any information is not delayed in his mind and is quickly replaced by new 3 . The success rate decreases and the learning rate decreases. People quickly forget what they have been taught recently and cannot master the works of classical literature ${ }^{5}$. Clinical medicine today faces two dangers: fetishization of technology and neglect of clinical thinking, which give rise to such a negative phenomenon in the medical environment as «feldsherism» («action - result», without taking into account the individual features of the patient, pathogenesis, mechanisms of effects, mechanisms of action, mechanisms of action,

However, the future doctor should be guided by a large number of new drugs, follow the guidelines of clinical protocols and doctrines, and his activities should be based on the principles of evidence-based medicine. He needs to analyze dozens of metrics at once. All of these symbols should be the same as a single analytical picture. The quality of work of a future doctor depends on how quickly and well he analyzes the information and makes decisions in a difficult situation. Sometimes it only takes seconds. Logical thinking is a priority for those who have too much time, but sometimes too little. Our specialty cannot be learned only through textbooks. The doctor should be able to think. You can read a lot of books, protocols,

${ }^{5}$ Yekhalov V.V., Sedinkin V.A., Barannyk S.I. (2017). «Klipove myslennya» ta suchasna vyshcha medychna osvita. Aktual'ni pytannya osvity i nauky: zbirnyk naukovykh statey, materialy V mizhnarodnoyi naukovo-praktychnoyi konferentsiyi 10-11 lystopada 2017 r. / Natsional'na akademiya Natsional'noyi hvardiyi Ukrayiny. Kharkiv: KHOHOKZ. 384 p. pp 172-178. 
recommendations and face a complication that is not spelled out. The most responsible task of the doctor is to find a solution in non-standard situations ${ }^{6}$.

The contradiction that arises between the vast amount of information we need to process and the growth of our workload is forcing our future colleague to «protect himself to survive.» So why not «turn your enemy into a friend» using the positives of clip-thinking, which:

- allows you to see the multifaceted, multivariate, ambiguous approaches to the analysis or solving specific issues and problems;

- creates an opportunity to protect against excessive flow of information;

- promotes greater adaptation to and changing social reality.

Clip thinking is negative only when it is related to the inability to determine the main thing. And if such an opportunity is, then in our time it becomes a strength, not a weakness. The control function focuses on the dynamic distribution of the attention of the anesthesiologist between numerous problems, routine and non-routine actions. Resource management is at the highest level of mentality, which knows all the available reserves. These two levels imply a flexible adaptation of the thinking process. This ability to «analyze thinking» in order to strategically control one's own mentality, called psychologists' metacognition, is a very important contribution to the successful resolution of critical situations in medical practice.

The «clip» way of working with information adds dynamism to cognitive learning activities, which allows us to manage, at least formally, the necessary tasks in the conditions of a growing amount of educational material: often we get to the situation when we mention something, but we are not completely sure of the accuracy of reproduction information. Clip behavior allows you to see the multifaceted, multivariate, ambiguous approaches to analyzing or solving specific issues and tasks (this thinking helps the audience to better understand and understand the wide variety of relationships between phenomena and events). Clip thinking can be used as a protective reaction of the body to information overload, contributes to greater adaptation to the changing social reality and its cognition; If we take into account all the information that a person sees and hears in a day, plus the «world dump» the Internet, then it is not surprising that her thinking

\footnotetext{
${ }^{6}$ Kligunenko Ye.N., Yekhalov V.V., Kushch Ye.A., Kravets O.V., Gayduk O.I., Barannik S.I., Khobotova N.V.(2019)/ Klipovoye myshleniye v anesteziologii: katastrofa ili zakonomernost’? Meditsina nevídkladnikh staní. № 3(98). pp. 111-123.
} 
changes, adapts, adapts to new conditions ${ }^{7}$. However, the "clip culture" is a reaction to social dynamics and an information boom that helps one's selfpreservation and adaptation to the environment. Thus, we can say that with the help of «clip thinking» a person escapes from the flow of information that presses on him. In general, in modern science, clip thinking is mostly referred to in a negative sense, in the context of a transformation of consciousness characterized by degradation. Many talk about superficial, eclectic, stereotypical perception of information. There are also some positive points: first, it is a security feature that cuts off a huge amount of information that is becoming more and more available, allowing you to get results quickly, using certain data. In any case, the factors that have provoked the formation of clip thinking are known, such as electronic publishing and network media, the Internet, mobile devices, ie technologies that are the driving force behind progress, which is known to be irreversible. Clip culture is becoming an integral component of the anthropological type of human information society. All this requires a separate thorough study ${ }^{8}$. Clip thinking «is a new form of development of human relations with information that needs to be widely studied.

\section{The aim of the study}

In our work we tried to analyze the impact of "clip thinking" on the ability of medical students to learn practical material during higher education, and to determine its level in different groups of students.

\section{Material and methods.}

The material for the study were the results of an anonymous survey of 300 students of the third year of medical faculty and interns who had a fulltime study at the Dnepropetrovsk Medical Academy of the Ministry of Health of Ukraine during the 2016/17 academic year (group A - 100 people), interns (group B - 100 people) and Group B (100 students of III year students) of the 2018/19 academic year. The questionnaire was used for the survey $^{9,10}$, which contained a diverse plan of 30 questions with two answer

\footnotetext{
${ }^{7}$ Litvinova M.B. (2017). Dosvid diahnos/tuvannya klipovoho myslennya. Pedahohichni nauky Vypusk LXXVI, Tom 3. pp. 140-145

Semenovskikh T. V. Fenomen (2014) «klipovogo myshleniya» v obrazovatel'noy vuzovskoy srede. Internet-zhurnal «Naukovedeniye», vip. 5(24). pp. 1-10.

${ }^{9}$ Kligunenko Ye.N., Yekhalov V.V., Kushch Ye.A., Kravets O.V., Gayduk O.I., Barannik S.I., Khobotova N.V.(2019)/ Klipovoye myshleniye v anesteziologii: katastrofa ili zakonomernost'? Meditsina nevídkladnikh staní. №3(98). pp. 111-123.

${ }^{10}$ Litvinova M.B. (2017). Dosvid diahnostuvannya klipovoho myslennya. Pedahohichni nauky Vypusk LXXVI, Tom 3. pp. 140-145.
} 
options, one of which was correct in determining the propensity for «clip thinking». The processing of the obtained data, their comparison with the given literary data of other researchers and two groups of own research allowed not only to evaluate its level but also to determine the personality of the mental approach to the use of this type of thinking by persons of different research groups.

\section{Research results.}

The data obtained from the students of group A showed that the average of correct answers (14.36) was 14\% of the respondents, 53\% of persons did not reach it and 33\% - exceeded this indicator. Group B interns showed a lower average of correct answers (12.0). It was reached by $10.25 \%$ of respondents, but the number of persons who did not reach it or surpassed it was the same $-44.87 \%$. But if you set an assessment criterion of 15 correct answers, then among students of group A who exaggerated it was $33 \%$, and among interns of group B - 17 persons (17\%). As for the students of group $\mathrm{B}$, the average of correct answers was 14.1 and it was reached by $17 \%$ of respondents. $37 \%$ of respondents in this group did not reach it but $46 \%$ exceeded this leper. Comparing with the 15 correct answer criterion, $36 \%$ of students who outperformed it, which is also more than in groups A and B. This may indicate positive trends in the evolutionary ability of the «clipthinking» ability. in the following age groups of students.

Qualitative analysis of the specific answers to the questionnaire showed that students are more likely to receive information through visual demonstration material compared to interns, but it is difficult for them to separate rational information from general terms, which takes a lot of time when working with specialized literature. This can be explained by the fact that they are in a state of accumulation of basic training material in comparison with the doctors-interns, which more consolidate the previously obtained level of knowledge. Despite having a strong commitment to using the latest computer technology to obtain information (72\% vs. $49 \%$ with interns), most students enjoy reading books (95\% vs. $75 \%$ with interns) whose content they remember best (79\% against 66\%) and trying to record for later use ( $93 \%$ vs. $75 \%)$.

Students have a better understanding of the material they study with the teacher $(80 \%$ vs. $64 \%)$ than what they have to get online. But it should be noted that lack of experience compels students to pay more attention to a thorough study of the object instead of forming a general idea about it (66\% 
vs. 55\%). The general analysis showed that modern students and interns are free to navigate in the modern rhythm of life, make good use of modern sources of information.

Qualitative comparative analysis conducted among students of groups A and B, separated by 2 years of study in the third course, showed the following data. Group B students were more resistant to possible third-party obstacles to gaining certain educational information. However, they equally used educational information and did not require special conditions for its receipt. In achieving the goal, they were more successful in solving problems of extreme help and making the right decision. However, a minimal amount of information was used. To obtain the necessary information carefully analyzed receiving it from electronic media, the Internet. It was believed that successful development without an information system similar to our computers is possible, but this requires a sufficient level of training. Like the students of group A, they enjoyed reading professional literature, but emphasized the benefits of visual information (videos, computer training programs). They are attracted to the stable situation, and they are still trying to make the necessary notes in lecture notes, as opposed to information on the Internet. To form a general idea of a phenomenon or object, they believe that there are ways to get information quickly.

The obtained data coincide with the data of previous studies and publications. ${ }^{11}$ Yes, students' negative clipping is more pronounced: this is due to the fact that teachers require them to study primary sources, educational literature, summarize and analyze specific information. and when they do not, the search for interactive learning and impact methods begins; Secondly, with the global informatization of society over the last ten years, the pace of information exchange has been accelerated, giving the young man the confidence to quickly solve a difficult task for him: why go to the library to take and then read a monograph on the subject when it is enough to open Google, to find, download from the network first (which almost never meets modern requirements) information, or openly tell the teacher: «Why prepare at home if you still explain everything to us.» This is already shaping the consumer approach to learning. A generation of «quick

\footnotetext{
${ }^{11}$ Nesterova L.YU., Napalkov S.V. (2016). Razvitiye klipovogo myshleniya u studentov v sisteme vysshego obrazovaniya posredstvom opornykh graf-skhem. Vestnik Nizhegorodskogo universiteta im. N.I. Lobachevskogo. Seriya: Sotsial'nyye nauki. № 4 (44). pp. 207 - 215.
} 
buttons» wants educational information to be provided to them in their usual, «clip» form (presentations of lessons, brief notes, reference schemes, drawings, etc.). These requirements are insufficiently addressed by the authors of new educational programs and modern textbooks. A person cannot concentrate on information for a long time, and his / her ability to analyze is significantly reduced. It is difficult for the clip-thinking owner to analyze the situation, as any information is not delayed in his mind and quickly changes to new ones. The success rate decreases and the learning rate decreases. People quickly forget what they have recently been taught and cannot master classical works.

The question here is about the ability to analyze and establish cause and effect relationships with the ability to quickly process finding information to switch from one subject to another. The task of finding the perfect proportion between the given properties is hard to imagine. Assuming that in the modern world the value of knowledge is determined only by its use in practice, the only criterion for the evaluation of this proportion can be considered for what purposes this knowledge is acquired. Obviously, in the information environment in which the modern man lives, the ability to quickly switch and process information is essential. The real question here is - is not the attempt to return to traditional text-centric pedagogy an attempt to "pull" today's reality into an already dying system of education that does not answer it? What can traditional education counter the network? Social networks that continue to win the world are increasingly integrated into the educational process - special communities are created where all kinds of tutorials, lectures, videos and audio are created, students ask teachers to send assignments there, because this way is more convenient than even email.

In this regard, it seems more progressive not to combat the spread of a new type of thinking, but to try to gradually reorganize the educational process to meet new requirements, integrate innovative tools and methods, increase its involvement in it, distribute classes into blocks for better learning. material, switching from one activity to another. If the latter conditions are met, however, it is necessary to summarize at the end of the lesson, logically linking the mentioned blocks. The need to implement these methods is due to all the same types of perception common to young people - visual and kinesthetic. Many modern students approach higher education from a purely practical point, which is facilitated, among other things, by the integration of universities into the Bologna process, which 
involves the introduction of a modular rating system of assessments. Students pay less and less attention to non-core subjects (general education unit). The advantages of literate tutorials made by this method are undeniable in the current situation, but it should not be forgotten that the creation of such manuals involves preliminary processing of information, that is, assumes that someone still works with the source. This is where the gap comes in - the clips are focused on the consumer of ready-made images and conclusions to which the author of the guide (author-mediator) draws the reader. There is a risk of distortion of information, falsification of facts, accentuation of some aspects and silence of others. Only the primary source makes it possible to form your own unbiased opinion about any subject and to consider it precisely from the side that subjectively seems to someone most interesting, otherwise, the reader risks being misled. One cannot ignore the fact that humanity has been steadily moving towards a new style of thinking over the centuries, which is likely to be just another stage in the development of mankind, a vector that one generation cannot change. The question of evaluating a new cognitive style remains open.

Modern education is incapable of forcing a person to create stable logical chains and to systematically qualify the data obtained. Instead, the number of people with cognitive thinking in the walls of higher education will increase every year. And it can lead to disaster if you do not look for ways to adapt the higher education system to the present.

In view of the above, we see the need to create alternative educational programs, to change the structure of information provision, to translate textbooks into a multilevel structure, where the first level would allow for a maximum of twenty minutes to get acquainted with the general idea in a couple of dozen «paragraph clips «, And each subsequent went deeper questions, systematizing the previously obtained knowledge. Books in this coordinate system will go to the last level and will also have to change qualitatively.

Addressing the issue of clinical thinking that senior teachers in medical colleges face requires detailed study. The inability of the student, even the «theoretical» honors student, to use, systematize the acquired knowledge every year causes more and more dissatisfaction and leads to a decrease in vocational training.

Another threat is endless testing. The situational task is a form traditionally used in the study of clinical disciplines. However, in most cases 
the tasks are designed in such a way as to limit creative activity. The tasks contain ready-made answers to the questions that arise in the objective examination of the patient (enlarged liver, determined ascites, etc.). As a rule, a set of clinical research methods is added, reflecting an idea of a given clinical condition from the position of the author of the situation of the compiler of the task, but not the student. The use of tests in education reduces the critical, analytical capacity of students, again forcing only the fragments of a particular phenomenon to be captured, without explaining its causes, patterns, without constructing logical circuits. Solving certain test tasks, we, of course, evaluate the level of knowledge (learning) of the student, but deprive him of the opportunity to think, and even to speak professionally. Therefore, supersaturation of various kinds of tests also adversely affects the formation of clinical thinking, which is the basis in medical universities.

It is advisable to make the class «outwardly attractive» - it can be a game form, giving examples from own experience, interesting tasks with practical results, etc. There should be a constant dialogue between the teacher and the students, they should be given the opportunity to independently (or consolidate) the necessary practical skills, to acquire modern diagnostic methods of research, as well as to prepare theoretical material in the form of a presentation on a highly specialized topic and to report to all students with further discussion. In the course of ethics-professional training, focused on personality, there must be a subject-subject relations. Efforts and active actions of all participants of the educational process are directed to selfdevelopment, self-realization of their own positive «I» - concept. The educational process is intended to ensure the integrity of the formation of the professional and civic status of young assistants while maintaining the individuality of each student's personality. It is this requirement that is one of the important aspects of becoming a socially-mature personality of a professional in higher education. A very important role is played by the creation of emotional and psychological comfort of the student in the process of submission of educational material. With the help of note taking you can design a model of the problem, both structural and conceptual. Summaries make it easier to remember the text. It will improve your ability to understand special terms. Writing in a concise way allows you to gather enough information needed to write a much more complex work, which will appear in the form of reports, abstracts, diploma and course papers, 
dissertations, articles, books. The process also includes «hand memory», that is, written. It is very important to give students an opportunity to understand why they have all this knowledge. This point should be explained as simply as possible (starting from the current political and economic environment).

It is proved that the system of increasing motivation to study is based on the systematic work of the teachers of the department to improve the level of professional and pedagogical skills. It is recommended to involve students in scientific work with the subsequent presentation of their results, as well as work and study outside the classroom under the supervision of the teacher with an objective assessment of the acquired knowledge and skills. It is the close collaboration between the teacher and the student in the classroom and extracurricular work, and the highly professional level of teaching using innovative teaching methods that make up the reserve to increase students' motivation for learning. The use of student activation methods is the most important principle of postgraduate study. Solution of diagnostic and medical problems, problem situations, participation in training games provides a sufficiently high professional training. In the learning process, students are forced to actively find, study and use educational and scientific information, which is more useful than traditional ways of teaching practical activity. The modern educational process actualizes the leadership qualities of young people, instilling in them a taste for the new and progressive, encouraging them to study the latest medical technologies.

\section{CONCLUSIONS}

Modern medical education requires the formation of a qualitatively new approach to the educational process, which will be based on the formation and development of clinical thinking, taking into account the psychological characteristics of modern youth. The «clip-on» way of working with information adds dynamism to cognitive learning activities, which allows, in the context of the growing volume of educational material, to manage, sometimes even formally, the necessary tasks. Clip behavior allows you to see the multifaceted, multivariate, ambiguous approaches to analyzing or solving specific issues and tasks (this thinking helps the audience to better understand and understand the wide variety of relationships between phenomena and events). However, it cannot neglect the negative consequences of this process. Constructing the educational process in accordance with the needs of the curriculum should take into account their 
own tasks against the background of progressive changes in the thinking of young people. The results may not be conclusive, but they do indicate a positive trend toward an evolutionary increase in the ability to «clip-think» in the following age groups of students. The results obtained coincide with the fact that the professional training of students who only master basic disciplines and interns who have completed the basic training course gives similar, but at the same time different data of the same survey. It is not possible to definitively determine in which group the level of "clip thinking" prevails. However, this fact testifies to the irreversibility of changes in «new thinking» that should be taken into account in teaching. Modern education is incapable of forcing a person to create stable logical chains and to systematically qualify the data obtained. Instead, the number of people with cognitive thinking in the walls of higher education will increase every year. And it requires looking for ways to adapt the higher education system to the present.

\section{SUMMARY}

The work is devoted development research «clip thinking» at medical students at various grade levels. The comparative analysis by results of poll of students and doctors-interns is carried out. It is noticed that «the clip thinking» influences reception of the information in the course of training. Positive dynamics of evolutionary changes in "clip thinking" among middle and senior students is noted. This circumstance should be considered at drawing up of curriculums and preparation for employment.

\section{REFERENCES}

1. Barannyk S.I., Yekhalov V.V., Romanyuta I.A., Lyashchenko P.V. (2018). Intehratsiya «klipovoho myslennya» v suchasnu vyshchu medychnu osvitu. Pivdennoukrayins'kyy medychnyy naukovy zhurnal. №19(19) february. pp. 8-12.

2. Barannyk S.I., Yekhalov V.V., Mizyakina K.V., Barannik K.S. (2019). Evolyutsiyni aspekty «Klipovoho myslennya» u studentiv-medykiv ta yikh intehratsiya u vyshchu medychnu osvitu. "Sotsial'no-humanitarni doslidzhennya ta innovatsiyna osvitnya diyal'nist'» Materialy Mizhnarodnoyi naukovoyi konferentsiyi. 24-25 travnya 2019 r., m. Dnipro / Nauk. red. O.YU. Vysots'kyy. Dnipro: SPD «Okhotnik». 528 P. pp 435-438. 
3. Hych H. M. (2016). «Klipove» myslennya molodi: druh chy voroh navchannya? Naukovi pratsi. Pedahohika, vipusk. 257. T. 269. p3.38-42.

4. Yekhalov V.V., Sedinkin V.A., Barannyk S.I. (2017). «Klipove myslennya» ta suchasna vyshcha medychna osvita. Aktual'ni pytannya osvity i nauky: zbirnyk naukovykh statey, materialy $\mathrm{V}$ mizhnarodnoyi naukovo-praktychnoyi konferentsiyi 10-11 lystopada 2017 r. / Natsional'na akademiya Natsional'noyi hvardiyi Ukrayiny. Kharkiv: KHOHOKZ. 384 p. pp. 172-178.

5. Yekhalov V.V., Samoylenko A.V., Romanyuta I.A., Barannyk S.I. (2018). Klinichne ta «klipove» myslennya u likariv-interniv. Ukrayins'kyy zhurnal medytsyny, biolohiyi ta sportu. Tom 3, №1(10). pp. 241-244.

6. Kligunenko Ye.N., Yekhalov V.V., Kushch Ye.A., Kravets O.V., Gayduk O.I., Barannik S.I., Khobotova N.V.(2019)/ Klipovoye myshleniye v anesteziologii: katastrofa ili zakonomernost'? Meditsina nevídkladnikh staní. №3(98). pp. 111-123.

7. Litvinova M.B. (2017). Dosvid diahnostuvannya klipovoho myslennya. Pedahohichni nauky Vypusk LXXVI, Tom 3. pp. 140-145.

8. Nesterova L.YU., Napalkov S.V. (2016). Razvitiye klipovogo myshleniya $\mathrm{u}$ studentov $\mathrm{v}$ sisteme vysshego obrazovaniya posredstvom opornykh graf-skhem. Vestnik Nizhegorodskogo universiteta im. N.I. Lobachevskogo. Seriya: Sotsial'nyye nauki. № 4 (44). pp. 207-215.

9. Semenovskikh T. V. Fenomen (2014) «klipovogo myshleniya» v obrazovatel'noy vuzovskoy srede. Internet-zhurnal «Naukovedeniye», vip. 5(24). pp. 1-10.

Information about the author: Barannik K. S., orcid.org/0000-0002-1009-4990 Candidate of Medical Sciences, Assistant at the Department of Urology Dnepropetrovsk Medical Academy of the Ministry of Health of Ukraine 9, Vernadsky str., Dnipro, 49044, Ukraine 